\title{
Synthesis, Characterization and in vitro Antimicrobial studies of Schiff-bases derived from Acetyl acetone and Amino acids and their Oxovanadium(IV) complexes
}

\author{
Misbah ur Rehman ${ }^{1}$, Muhammad Imran ${ }^{2, ~ *, ~ M u h a m m a d ~ A r i f ~}{ }^{2}$ \\ ${ }^{1}$ Institute of Chemical Science, Gomal University, D.I. Khan, KPK, Pakistan \\ ${ }^{2}$ Institute of Chemical Science, Bahauddin Zakariya University, Multan, Pakistan \\ Email address: \\ imran345@hotmail.com (M. Imran)
}

\section{To cite this article:}

Misbah ur Rehman, Muhammad Imran, Muhammad Arif. Synthesis, Characterization and in Vitro Antimicrobial Studies of Schiff-Bases Derived from Acetylacetone and Amino Acids and their Oxovanadium(IV) Complexes. American Journal of Applied Chemistry.

Vol. 1, No. 4, 2013, pp. 59-66. doi: 10.11648/j.ajac.20130104.13

\begin{abstract}
A series of novel amino acid derived Schiff-bases and their Oxovanadium(IV) complexes were synthesized and well characterized by elemental analyses, spectral studies, conductivity and magnetic measurements. Physical and analytical data suggest that the Schiff bases act as tridentate ligands towards metal ion via azomethine-N, deprotonated-O of carboxylic group and enolic-O group of acetylacetone. All the complexes have lower molar conductance values, indicating their non-electrolytic nature. The synthesized ligands, along with their metal complexes were screened for their in-vitro antibacterial activity against two Gram-negative (Escherichia coli, Salmonella typhi) and two Gram-positive (Bacillus subtilis, Staphylococcus aureus) bacterial strains and for in vitro antifungal activity against Trichophyton longifusus, Candida albicans, Aspergillus flavus, and Candida glaberata species. The results of these studies revealed that all the compounds and their metal complexes showed significant antibacterial and antifungal potency. Brine shrimp bioassay was also carried out for in vitro cytotoxic properties against Artemia salina.
\end{abstract}

Keywords: Schiff-bases, Amino Acid, Antibacterial, Antifungal, Cytotoxicity

\section{Introduction}

Schiff base are an important class of ligands in coordination chemistry due to not only their useful physical and chemical properties and large number of reactions they undergo but also have very wide use in industry and due to their interesting pharmacological as well as physiological activities.[1,2] They are also important intermediate in the enzymatic reactions involving interaction of an enzyme with an amino or a carbonyl group of the substrate.[3] It is possible to introduce different substituents into the existing skeleton of the molecule, hence enabling the designing of compounds with the suitable structural, electronic and biological properties.[4] In recent years, Schiff base complexes of amino acid have received considerable attention because of their physiological and pharmacological activities.[5,6] In metal coordination chemistry Schiff bases continue to occupy an important position as ligand ions due to the incorporation of transition metals into Schiff bases. This results in an increase in biological activity of the ligand and decrease in the cytotoxic effects of both the metal ion and ligand on the host.[7] Metal ions play a catalytic role in reactions of Schiff bases. The development in the field of bioinorganic chemistry has increased the interest in Schiff base complexes, since it has been recognized that many of these complexes may serve as models for biologically important species. It have also been reported that metal complexes of amino acid Schiff bases possess anti-carcinogenic activities. [8] The coordination behavior of schiff bases with Vanadium is of great interest because of the presence of Vanadium in biological systems as trace element. The geometry of vanadyl complexes is highly dependent on the chelating properties of ligands.[9,10] It have been observed that schiff bases form stable complexes with oxovanadium(IV) salts with five or six coordinated state of V(IV).[11] A square pyramidal or distorted trigonal bipyramidal geometry is reported for five coordinated complexes[12] while distorted octahedral structure is observed for the six coordinated ones.[13] In past few years attentions have been focused on the synthesis of low 
toxicity bacteriostatic agents and it have been observed that Vanadyl ion is less toxic than vanadate ion. Keeping in view the importance of Schiff base oxovanadium(IV) complexes, in present studies, we have prepared four ligands $\left(\mathrm{L}_{1}-\mathrm{L}_{4}\right)$ by the condensation reaction between amino acids (Tyrosin, Threonin, Lysin, Arginin) and acetylacetone with this hope that it may provide us valuable theoretical information for exploring metal-based anti-microbial and carcinogenic agents with high efficiancy and low toxicity. The synthesized amino acid-derived schiff bases $\left(\mathrm{L}_{1}-\mathrm{L}_{4}\right)$ have been exposed to act as tri-dentate towards vanadyl ion through the azomethine-N, carboxylat-O and enolic-O groups forming 5 and 6 membered stable chelate ring system.

\section{Experimental}

\subsection{Materials and Physical Measurements}

All the reagents and solvents were purchased from Sigma-Aldrich and they were used as received. Reactions were monitored by thin layer chromatography (plates coated with $0.2 \mathrm{~mm}$ Merck 60 F254 silica gel) and were visualized by UV irradiation $(254 \mathrm{~nm})$. Elemental analyses were carried out with a LECO-CHNS-9320 model. ${ }^{1} \mathrm{H}$ and ${ }^{13} \mathrm{C}$-NMR spectra of compounds were recorded with a Bruker Spectrospin Avance DPX-400 using TMS as internal standard and $\mathrm{d}_{6}$ DMSO as solvent. Infrared spectra of compounds were recorded on a Philips Analytical PU 9800 FTIR spectrophotometer. The melting points of compounds were determined with a Gallenkamp melting point apparatus. UV/visible absorption spectra were recorded using a Shimadzu UV-1700 spectrophotometer at room temperature. Conductance was recorded by pre-calibrated cyber scan 500 conductivity meter. Electron impact mass spectra (EIMS) were recorded on a JEOL MS Route instrument. Thermogravimetric analysis (TGA) was carried out under constant nitrogen flow at a heating rate of $15^{\circ} \mathrm{C} \mathrm{min}^{-1}$, using a Mettler Toledo TGA/SDTA 851 balance. The heating scans were performed on 3-5 $\mathrm{mg}$ of sample, in the temperature range $25-900{ }^{\circ} \mathrm{C}$. In vitro antibacterial, antifungal and cytotoxic properties were studied at HEJ Research Institute of Chemistry, International Center for Chemical Sciences, University of Karachi, Pakistan.

\subsection{Synthesis and Characterization of Schiff Bases}

To a stirred solution of respective amino acid (20 mmol in $20 \mathrm{ml}$ water) was added acetylacetone $(20 \mathrm{mmol}$ in 10 $\mathrm{ml}$ ethanol). To this solution $\mathrm{K}_{2} \mathrm{CO}_{3}(0.1 \%$ in ethanol) was added to adjust the $\mathrm{pH}$ of the solution at $7-8$. The resulting reaction mixture was refluxed on water bath for $3 \mathrm{~h}$. The completion of the reaction was monitored by TLC. After completion of the reaction, the volume of the mixture was reduced to half in vacuo. On cooling a solid product was formed, filtered, washed with ethanol, then with ether, and dried. (Scheme 1).

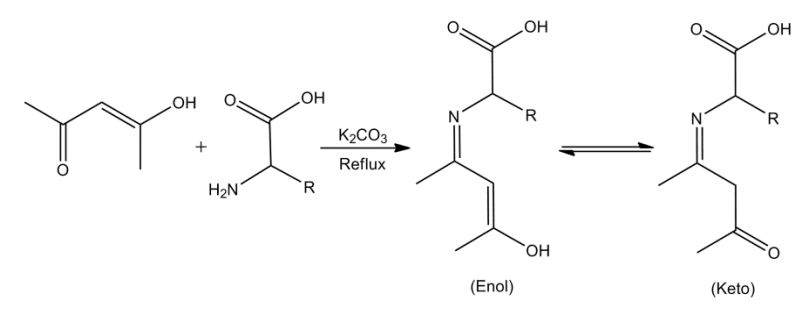

Scheme 1. Synthesis of Schiff bases.

\subsection{Compound 1, $\left(L_{1}\right)$}

(R)-2-((4-Hydroxypent-3-En-2-Ylidene)

Amino)-3-(4-Hydroxyphenyl) Propanoic Acid

Yellow solid; yield 70\%; m.p: $210{ }^{\circ} \mathrm{C}$; Anal. Calcd. For $\mathrm{C}_{14} \mathrm{H}_{17} \mathrm{NO}_{4}$ : C, 63.64; H, 6.62; N, 5.28\%. Found: C, 63.87; H, $6.51 ; \mathrm{N}, 5.32 \%$; IR $\left(\mathrm{KBr}, \mathrm{cm}^{-1}\right): 3436$ (-OH stretching), 3055 (-CH stretching of aromatic ring), 2962 (-CH stretching of $\mathrm{CH}_{3}$ ), 2922 (-CH stretching of aliphatic group), $1708(-\mathrm{C}=\mathrm{O}$ stretching), $1625(\mathrm{C}=\mathrm{C}$ stretchig), $1610(\mathrm{C}=\mathrm{N}$ stretching), 1346 (C-N stretching), 1236 (C-O stretching of phenolic group); ${ }^{1} \mathrm{H}-\mathrm{NMR}$ (400 MHz, DMSO-d $\left.6, \delta / \mathrm{ppm}\right): 12.2(1 \mathrm{H}$, $\mathrm{s}, \mathrm{OH}), 11.3(1 \mathrm{H}, \mathrm{s}, \mathrm{COOH}), 8.7(1 \mathrm{H}, \mathrm{s}, \mathrm{OH}$, Phenolic $), 7.2$ $(2 \mathrm{H}, \mathrm{d}$, Aromatic, J $=1.5 \mathrm{~Hz}), 6.8(2 \mathrm{H}, \mathrm{d}$, Aromatic, $\mathrm{J}=3.8$ $\mathrm{Hz}), 5.1(1 \mathrm{H}, \mathrm{s}, \mathrm{HC}=\mathrm{C}), 2.9(1 \mathrm{H}, \mathrm{m}, \mathrm{N}-\mathrm{CH}-\mathrm{C}), 2.7(2 \mathrm{H}, \mathrm{d}$, Aliphatic $\left.\mathrm{CH}_{2}, \mathrm{~J}=7.5 \mathrm{~Hz}\right), 2.2\left(3 \mathrm{H}, \mathrm{s}, \mathrm{CH}_{3}\right), 2.1(3 \mathrm{H}, \mathrm{s}$, $\left.\mathrm{N}=\mathrm{C}-\mathrm{CH}_{3}\right) ;{ }^{13} \mathrm{C}$ NMR (400 MHz, DMSO-d 6 , $\left.\delta / \mathrm{ppm}\right): 180.2$ (C7, COO), $178.3(\mathrm{C} 2, \mathrm{COH}), 162.1(\mathrm{C} 4, \mathrm{C}=\mathrm{N}), 157.6(\mathrm{C} 12$, Aromatic), 128.2 (C9, Aromatic), 122.5 (C10 and $\mathrm{C} 14$ Aromatic), 112.6 C11 and $\mathrm{C} 13$, Aromatic), $80.2(\mathrm{C} 3, \mathrm{CH})$, $71.1(\mathrm{C} 6, \mathrm{CH}), 40.3\left(\mathrm{C} 8\right.$, Aliphatic $\left.\mathrm{CH}_{2}\right), 27.6\left(\mathrm{C} 1, \mathrm{CH}_{3}\right)$, $14.5\left(\mathrm{C} 5, \mathrm{CH}_{3}\right)$; MS (ESI) [M] $]^{+} 263$.

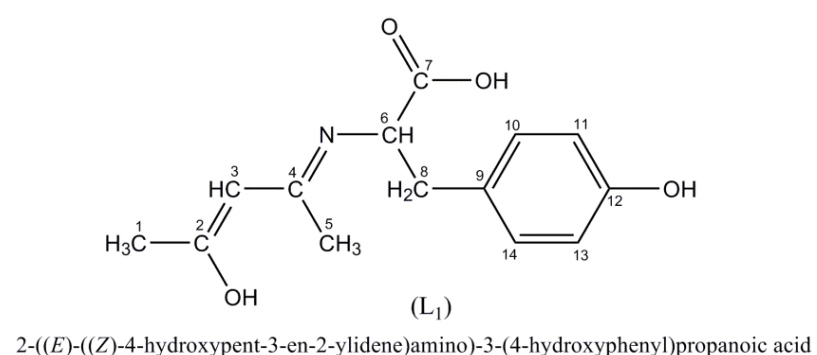

Figure 1. Structure of the ligand $\left(L_{1}\right)$

\subsection{Compound 2, $\left(\mathrm{L}_{2}\right)$ (2S)-3-Hydroxy-2-((4-Hydroxypent-3-En-2-Ylidene) Amino) Butanoic Acid}

Yellow solid; yield 68\%; m.p: $208{ }^{\circ} \mathrm{C}$; Anal. Calcd. For $\mathrm{C}_{9} \mathrm{H}_{15} \mathrm{NO}_{4}$ : C, 53.72; H, 7.51; N, 6.96. Found: C, 53.69; H, 7.53; N, 6.92; IR (KBr, cm $\left.{ }^{-1}\right): 3446$ (-OH stretching), 2954 (-CH stretching of $\left.\mathrm{CH}_{3}\right), 2896$ (-CH stretching of aliphatic $\mathrm{CH}), 1714$ ( $-\mathrm{C}=\mathrm{O}$ stretching), $1632(\mathrm{C}=\mathrm{C}$ stretchig), 1614 $(\mathrm{C}=\mathrm{N}$ stretching), 1342 (C-N stretching), $1104 \quad(\mathrm{C}-\mathrm{O}$ stretching of alcoholic group); ${ }^{1} \mathrm{H}-\mathrm{NMR}(400 \mathrm{MHz}$, DMSO-d $\left._{6}, \delta / \mathrm{ppm}\right): 12.8(1 \mathrm{H}, \mathrm{s}, \mathrm{C}=\mathrm{C}-\mathrm{OH}), 11.2(1 \mathrm{H}, \mathrm{s}$, 
$\mathrm{COOH}), 5.2(1 \mathrm{H}, \mathrm{s}, \mathrm{HC}=\mathrm{C}), 4.1(1 \mathrm{H}, \mathrm{s}, \mathrm{C}-\mathrm{OH}), 3.8(1 \mathrm{H}, \mathrm{m}$, $\mathrm{CH}), 2.4(1 \mathrm{H}, \mathrm{d}, \mathrm{N}-\mathrm{CH}), 2.3\left(3 \mathrm{H}, \mathrm{s}, \mathrm{C}=\mathrm{C}-\mathrm{CH}_{3}\right), 2.1(3 \mathrm{H}, \mathrm{s}$, $\left.\mathrm{N}=\mathrm{C}-\mathrm{CH}_{3}\right), 1.4\left(3 \mathrm{H}, \mathrm{d}, \mathrm{CH}_{3}, \mathrm{~J}=7.4 \mathrm{~Hz}\right) ;{ }^{13} \mathrm{C}$ NMR $(400$ MHz, DMSO-d6, $\delta / \mathrm{ppm}): 175.5$ (C7, COO), 172.2 (C2, $\mathrm{C}-\mathrm{OH}), 162.4(\mathrm{C} 4, \mathrm{C}=\mathrm{N}), 80.1(\mathrm{C} 3, \mathrm{HC}=\mathrm{C}), 68.5(\mathrm{C} 8$, $\mathrm{HC}-\mathrm{OH}), 64.3(\mathrm{C} 6, \mathrm{~N}-\mathrm{CH}), 20.6\left(\mathrm{C} 9, \mathrm{CH}_{3}\right), 17.5\left(\mathrm{C} 1, \mathrm{CH}_{3}\right)$, $14.5\left(\mathrm{C} 5, \mathrm{CH}_{3}\right)$; MS (ESI) $[\mathrm{M}]^{+}: 201$.

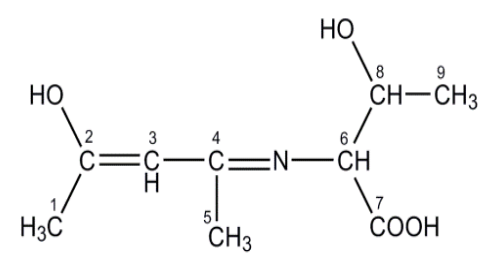

$\left(\mathrm{L}_{2}\right)$

(2S)-3-hydroxy-2-((4-hydroxypent-3-en-2-ylidene)amino)butanoic acid

Figure 2. Structure of the ligand $\left(L_{2}\right)$

\subsection{Compound 3, $\left(L_{3}\right)$}

(S)-6-Amino-2-((4-Hydroxypent-3-En-2-Ylidene) Amino) Hexanoic Acid

Yellow solid; yield 74\%; m.p: $194{ }^{\circ} \mathrm{C}$; Anal. Calcd. For $\mathrm{C}_{11} \mathrm{H}_{20} \mathrm{~N}_{2} \mathrm{O}_{3}$ : C, 57.87; H, 8.83; N, 12.27. Found: C, 57.83; $\mathrm{H}, 8.76 ; \mathrm{N}, 12.35$; IR ( $\left.\mathrm{KBr}, \mathrm{cm}^{-1}\right): 3438$ (-OH stretching), 3392 ( NH stretching), 2962 (-CH stretching of $\left.\mathrm{CH}_{3}\right), 2932$ (-CH stretching of $\mathrm{CH}_{2}$ ), 2892 (-CH stretching of aliphatic $\mathrm{CH}), 1720$ ( $\mathrm{C}=\mathrm{O}$ stretching), 1625 ( $\mathrm{C}=\mathrm{C}$ stretchig), 1606 $(\mathrm{C}=\mathrm{N}$ stretching), $1586 \quad(\mathrm{NH}$ bending), $1337 \quad(\mathrm{C}-\mathrm{N}$ stretching), 1102 (C-O stretching of alcoholic group); ${ }^{1} \mathrm{H}-\mathrm{NMR}$ (400 MHz, DMSO-d 6 , $\left.\delta / \mathrm{ppm}\right): 12.4(1 \mathrm{H}, \mathrm{s}$, $\mathrm{C}-\mathrm{OH}), 11.2(1 \mathrm{H}, \mathrm{s}, \mathrm{COOH}), 5.3\left(2 \mathrm{H}, \mathrm{m}, \mathrm{NH}_{2}\right), 5.1(1 \mathrm{H}, \mathrm{s}$, $\mathrm{HC}=\mathrm{C}), 2.8\left(2 \mathrm{H}, \mathrm{m}, \mathrm{N}-\mathrm{CH}_{2}\right), 2.5(1 \mathrm{H}, \mathrm{m}, \mathrm{N}-\mathrm{CH}), 2.3(3 \mathrm{H}, \mathrm{s}$, $\mathrm{CH} 3), 2.1\left(3 \mathrm{H}, \mathrm{s}, \mathrm{N}=\mathrm{C}-\mathrm{CH}_{3}\right), 1.8\left(2 \mathrm{H}, \mathrm{m}, \mathrm{CH}_{2}\right), 1.6(2 \mathrm{H}, \mathrm{m}$, $\left.\mathrm{CH}_{2}\right), 1.3\left(2 \mathrm{H}, \mathrm{m}, \mathrm{CH}_{2}\right) ;{ }^{13} \mathrm{C}$ NMR $\left(400 \mathrm{MHz}, \mathrm{DMSO}-\mathrm{d}_{6}, \delta\right.$ / ppm): 180.2 (C7, COO), $174.2(\mathrm{C} 2, \mathrm{C}=\mathrm{CH}), 168.2$ (C4, $\mathrm{C}=\mathrm{N}), 82.4(\mathrm{C} 3, \mathrm{CH}=\mathrm{C}), 65.2(\mathrm{C} 6, \mathrm{~N}-\mathrm{CH}), 45.2(\mathrm{C} 11$, $\left.\mathrm{CH}_{2}-\mathrm{NH}_{2}\right), 36.2\left(\mathrm{C} 10, \mathrm{CH}_{2}\right), 34.4\left(\mathrm{C} 8, \mathrm{CH}_{2}\right), 24.2(\mathrm{C} 9$, $\left.\mathrm{CH}_{2}\right), 19.6\left(\mathrm{C} 1, \mathrm{CH}_{3}\right), 14.2\left(\mathrm{C} 5, \mathrm{CH}_{3}\right) ; \mathrm{MS}(\mathrm{ESI})[\mathrm{M}]^{+}$: 228.

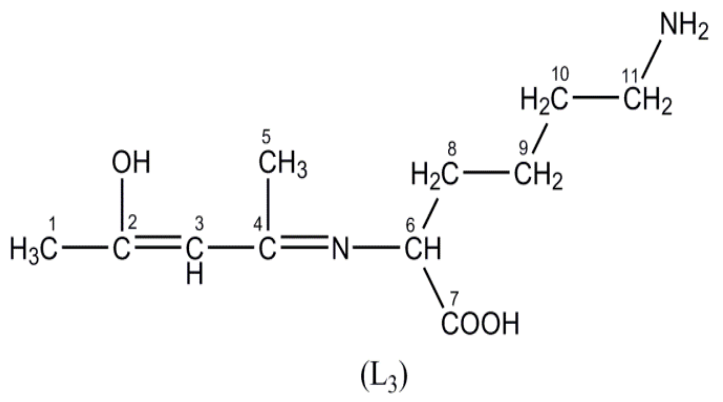

(S)-6-amino-2-((4-hydroxypent-3-en-2-ylidene)amino)hexanoic acid

Figure 3. Structure of the ligand $\left(L_{3}\right)$

\subsection{Compound 4, $\left(L_{4}\right)$ 5-Guanidino-2-((E)-((E)-4-Hydroxypent-3-En-2-Ylide ne) Amino) Pentanoic Acid}

Yellow solid; yield $72 \%$; m.p: $185{ }^{\circ} \mathrm{C}$; Anal. Calcd. For $\mathrm{C}_{11} \mathrm{H}_{20} \mathrm{~N}_{4} \mathrm{O}_{3}$ : C, 51.55; H, 7.87; N, 21.86. Found: C, 51.47; $\mathrm{H}, 7.68 ; \mathrm{N}, 21.92$; IR ( $\left.\mathrm{KBr}, \mathrm{cm}^{-1}\right): 3442$ (-OH stretching), 3375 (NH stretching), 2970 (-CH stretching of $\left.\mathrm{CH}_{3}\right), 2940$ (-CH stretching of $\left.\mathrm{CH}_{2}\right), 2898$ (-CH stretching of aliphatic $\mathrm{CH}), 1714(-\mathrm{C}=\mathrm{O}$ stretching), $1632(\mathrm{C}=\mathrm{C}$ stretchig $), 1610$ $(\mathrm{C}=\mathrm{N}$ stretching), 1595 ( $\mathrm{NH}$ bending of primary amine), 1565 ( NH bending of secondry amine), 1337 (C-N stretching), 1298 (C-N stretching of secondry amine), 1276 (C-N stretching of primary amine), 1095 (C-O stretching of alcoholic group); ${ }^{1} \mathrm{H}-\mathrm{NMR}(400 \mathrm{MHz}$, DMSO-d $\left._{6}, \delta / \mathrm{ppm}\right): 12.8(1 \mathrm{H}, \mathrm{s}, \mathrm{C}-\mathrm{OH}), 11.2(1 \mathrm{H}, \mathrm{s}$, $\mathrm{COOH}), 8.4\left(2 \mathrm{H}, \mathrm{s}, \mathrm{NH}_{2}\right), 5.2(1 \mathrm{H}, \mathrm{s}, \mathrm{HC}=\mathrm{C}), 4.8(1 \mathrm{H}, \mathrm{m}$, $\mathrm{HN}=\mathrm{C}), 3.4(1 \mathrm{H}, \mathrm{m}, \mathrm{NH}), 2.7\left(2 \mathrm{H}, \mathrm{m}, \mathrm{CH}_{2}-\mathrm{NH}\right), 2.5(1 \mathrm{H}$, m, HC-N), $2.3\left(3 \mathrm{H}, \mathrm{s}, \mathrm{CH}_{3}\right), 2.1\left(3 \mathrm{H}, \mathrm{s}, \mathrm{N}=\mathrm{C}-\mathrm{CH}_{3}\right), 1.8(2 \mathrm{H}$, $\left.\mathrm{m}, \mathrm{CH}_{2}\right), 1.5\left(2 \mathrm{H}, \mathrm{m}, \mathrm{CH}_{2}\right) ;{ }^{13} \mathrm{C}$ NMR $\left(400 \mathrm{MHz}, \mathrm{DMSO}-\mathrm{d}_{6}\right.$, $\delta / \mathrm{ppm}): 179.2$ (C7, COO), $176.2(\mathrm{C} 2, \mathrm{C}-\mathrm{OH}), 162.4(\mathrm{C} 4$, $\mathrm{C}=\mathrm{N}), 156.5(\mathrm{C} 11, \mathrm{C}=\mathrm{NH}), 85.2(\mathrm{C} 3, \mathrm{HC}=\mathrm{C}), 70.2(\mathrm{C} 6$, HC-N), $42.6\left(\mathrm{C} 10, \mathrm{HN}-\mathrm{CH}_{2}\right), 38.4\left(\mathrm{C} 8, \mathrm{CH}_{2}\right), 26.6(\mathrm{C} 9$, $\left.\mathrm{CH}_{2}\right), 18.6\left(\mathrm{Cl}, \mathrm{CH}_{3}\right), 14.2\left(\mathrm{C} 5, \mathrm{CH}_{3}\right)$; MS (ESI) $[\mathrm{M}]^{+}: 256$.

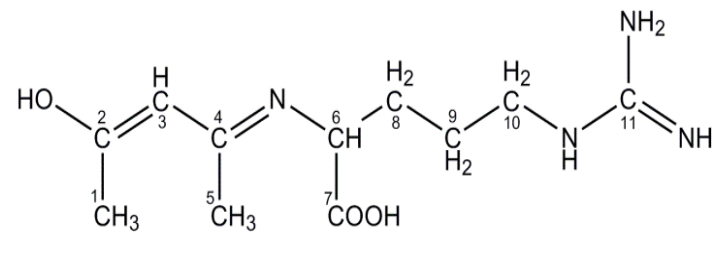

$\left(\mathrm{L}_{4}\right)$

5-guanidino-2-((E)-((E)-4-hydroxypent-3-en-2-ylidene)amino)pentanoic acid

Figure 4. Structure of the ligand $\left(L_{4}\right)$

\subsection{Synthesis of Oxovanadium(IV) Complexes}

To a hot magnetically stirred ethanol solution of Schiff bases $\left(\mathrm{L}_{1}-\mathrm{L}_{4}, 0.1\right.$ mole $)$, an ethanolic solution of metal salt ( 0.1 mole) was added. The mixture was then refluxed for 2-12 h. The completion of reaction was monitored by TLC. The solution obtained was cooled at room temprature, precipitates appeared were filtered and washed with ethanol and dried. (Scheme 2).

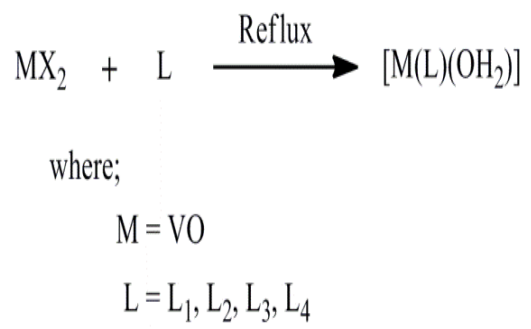

Scheme 2. Synthesis of oxovanadium(IV) complexes. 


\subsection{Antibacterial Activity}

The in-vitro antibacterial activity of Schiff bases $\left(\mathrm{L}_{1}-\mathrm{L}_{4}\right)$ and their oxovanadium complexes $\left(\mathrm{C}_{1}-\mathrm{C}_{4}\right)$ was assayed against two Gram-negative (Escherichia coli, Salmonella typhi) and two Gram-positive (Staphylococcus aureus, Bacillus subtilis) bacterial strains by the reported method.[14] The stock solution $(1 \mathrm{mg} / \mathrm{ml})$ of the test chemical was prepared by dissolving $10 \mathrm{mg}$ of the test compound in $10 \mathrm{ml}$ of Dimethyl sulfoxide (DMSO) solvent. The stock solution was suitably diluted with sterilized distilled water to get dilution of 100,50 and $25 \mathrm{mgml}^{-1}$. Control for each dilution was prepared by diluting $10 \mathrm{ml}$ of solvent instead of stock solution with sterilized distilled water. The wells (6 $\mathrm{mm}$ in diameter) were dug in the agar media with the help of a sterile metallic borer. Two to eight hours old bacterial inocula containing approximately 104-106 colony forming units (CFU/mL) were spread on the surface of the nutrient agar with the help of a sterile cotton swab. The prepared concentrations of the test sample were introduced in the respective wells. Other wells supplemented with DMSO and reference antibacterial drug, Imipenem, served as negative and positive controls, respectively. The plates were incubated immediately at $37{ }^{\circ} \mathrm{C}$ for $24 \mathrm{~h}$. Activity was determined by measuring the diameter of zones showing complete inhibition ( $\mathrm{mm}$ ). In order to clarify any effect of DMSO in the biological screening, separate studies were carried out with the solutions alone of DMSO and they showed no activity against any bacterial strains.

\subsection{Antifungal Activity}

All the compounds $\left(\mathrm{L}_{1}-\mathrm{L}_{4}\right)$ and their oxovanadium complexes $\left(\mathrm{C}_{1}-\mathrm{C}_{4}\right)$ were studied against four fungal cultures (Trichophyton longifusus, Candida albicans, Aspergillus flavus, and Candida glaberata) for Antifungal activities. Sabouraud dextrose agar (Oxoid, Hampshire, England) was seeded with $105 \mathrm{cfu} \mathrm{ml}^{-1}$ fungal spore suspensions and transferred to petri plates. The stock solution of test chemical was prepared and diluted to 100 , 50 and $25 \mathrm{mgml}^{-1}$. Discs soaked in $20 \mathrm{ml}$ of prepared concentrations of all compounds were placed at different positions on the agar surface. The plates were incubated at $32{ }^{\circ} \mathrm{C}$. The percentage inhibition was calculated after seven days and compared with standard drugs Miconazole.[15]

\subsection{In Vitro Cytotoxicity}

The synthesized compounds and their oxovanadium(IV) complexes were screened for their cytotoxicity (brine shrimp bioassay) by using the protocol of Meyer et al. [16] Brine shrimp (Artemia salina leach) eggs were hatched in a shallow rectangular plastic dish $(22 \times 32 \mathrm{~cm})$ filled with artificial seawater, which was prepared with a commercial salt mixture and double distilled water. An unequal partition was made in the plastic dish with the help of a perforated device. Approximately $50 \mathrm{mg}$ of eggs were sprinkled into the large compartment, which was darkened while the minor compartment was open to ordinary light. After two days nauplii were collected by a pipette from the lighted side. A sample of the test compound was prepared by dissolving $20 \mathrm{mg}$ of each compound in $2 \mathrm{ml}$ of DMSO. From this stock solution 100, 50 and $25 \mathrm{mgml}^{-1}$ were transferred to nine vials (three for each dilutions were used for each test sample and $\mathrm{LD}_{50}$ is the mean of three values) and one vial was kept as control having $2 \mathrm{ml}$ of DMSO only. The solvent was allowed to evaporate overnight. After two days, when shrimp larvae were ready, $1 \mathrm{ml}$ of seawater and 10 shrimps were added to each vial (30 shrimps/dilution) and the volume was adjusted with seawater to $5 \mathrm{ml}$ per vial. After $24 \mathrm{~h}$ the number of survivors was counted. Data were analyzed by a Finney computer program to determine the $\mathrm{LD}_{50}$ values.[17]

\section{Results and Discussion}

\subsection{IR Spectra}

In order to study the bonding mode of ligand to metal in the complexes, IR spectrum of free ligands was compared with the complexes. The structurally significant IR band for ligands and their complexes have been reported in the Experimental and Table I respectively. Acetylacetone is capable of exhibiting keto-enol tautomerism and react with metal cations to form metal complexes. The IR spectra of all the ligands show the absence of bands at 3245 and 1745 $\mathrm{cm}^{-1}$ due to $v\left(\mathrm{HN}_{2}\right)$ group of amino acids and $v(\mathrm{C}=\mathrm{O})$ of acetylacetone.[18] Instead, a new prominent band at 1606-1614 $\mathrm{cm}^{-1}$ due to azomethine $v(\mathrm{C}=\mathrm{N})$ linkage appeared in all the ligands indicating [19] that condensation between ketone moiety of acetylacetone and that of amino group of amino acid has taken place resulting into the formation of the desired ligands $\left(\mathrm{L}_{1}-\mathrm{L}_{4}\right)$. IR spectra of the oxovanadium(IV) complexes showed[20] a major shift to lower wave numbers by $15-20 \mathrm{~cm}^{-1}$ in azomethine $v(\mathrm{C}=\mathrm{N})$ suggesting involvement of the azomethine- $\mathrm{N}$ with the metal(II) ion. This is further supported by the appearance of new bands at 450-486 $\mathrm{cm}^{-1}$ due to $v(\mathrm{M}-\mathrm{N})$ bond.[21] Also, disappearance of the stretching frequency at 1700-1708 $\mathrm{cm}^{-1}$ assigned to $v(\mathrm{COOH})$ and appearance of new bands of the $\left(-\mathrm{CO}_{2}\right)$ group at 1590 and $1385 \mathrm{~cm}^{-1}$, is consistent with carboxylate coordination with the metal atom. The shifting of medium to high intensity bands of enolic $\mathrm{C}-\mathrm{O}$ bond towards higher frequency $\left(1339-1368 \mathrm{~cm}^{-1}\right)$ and appearance of new bands at $510-540 \mathrm{~cm}^{-1}$ support the formation of $\mathrm{M}-\mathrm{O}$ bond via de-protonation.[22] The presence of coordinated water molecule in the complex is indicated by the appearance of a broad band at $3226-3460 \mathrm{~cm}^{-1}$ and two weak bands in the region 754-784 $\mathrm{cm}^{-1}$ and $700-718 \mathrm{~cm}^{-1}$ due to $(-\mathrm{OH})$ rocking and wagging mode of vibrations, respectively. Apart from this, the infrared spectra of the $\mathrm{VO}^{2+}$ also exhibit a strong band at $996-970 \mathrm{~cm}^{-1}$ which is 
attributed to the terminal $\mathrm{V}=\mathrm{O}$ bond. These overall data suggest that the azomethine- $\mathrm{N}$, carboxylate- $\mathrm{O}$ and enolic-O groups are involved in coordination with the metal(II) ion in complexes $\left(\mathrm{C}_{1}-\mathrm{C}_{4}\right)$.

Table 1. The important infrared frequencies (in $\mathrm{cm}^{-1}$ ) of oxovanadium complexes.

\begin{tabular}{cccccccc}
\hline Code & Complex & $\boldsymbol{v}(\mathbf{C}=\mathbf{N})$ & $\boldsymbol{v}(\mathbf{M}-\mathbf{N})$ & $\boldsymbol{v}(\mathbf{M}-\mathbf{O})$ & $\boldsymbol{v}(\mathbf{C}-\mathbf{O})$ & $\boldsymbol{v}(\mathbf{C}=\mathbf{C})$ \\
\hline $\mathrm{C}_{1}$ & {$\left[\mathrm{VO}\left(\mathrm{L}_{1}\right)\left(\mathrm{OH}_{2}\right)\right]$} & $1590 \mathrm{~s}$ & $455 \mathrm{~m}$ & $510 \mathrm{~m}$ & $1232 \mathrm{~m}$ & 1624 \\
$\mathrm{C}_{2}$ & {$\left[\mathrm{VO}\left(\mathrm{L}_{2}\right)\left(\mathrm{OH}_{2}\right)\right]$} & $1594 \mathrm{~m}$ & $462 \mathrm{~m}$ & $540 \mathrm{~m}$ & $1103 \mathrm{~m}$ & 1630 \\
$\mathrm{C}_{3}$ & {$\left[\mathrm{VO}\left(\mathrm{L}_{3}\right)\left(\mathrm{OH}_{2}\right)\right]$} & $1591 \mathrm{~m}$ & $458 \mathrm{~m}$ & $535 \mathrm{~m}$ & $1101 \mathrm{~m}$ & 1623 \\
$\mathrm{C}_{4}$ & {$\left[\mathrm{VO}\left(\mathrm{L}_{4}\right)\left(\mathrm{OH}_{2}\right)\right]$} & $1594 \mathrm{~m}$ & $460 \mathrm{~m}$ & $512 \mathrm{~m}$ & $1093 \mathrm{~m}$ & 1629 \\
\hline
\end{tabular}

\section{2. ${ }^{1} \mathrm{H}$ NMR Spectra}

The ${ }^{1} \mathrm{H}$ NMR spectral data along with the possible assignments are reported in "Experimental." All the protons were found as to be in their expected region.[23] The ${ }^{1} \mathrm{H}-\mathrm{NMR}$ spectra of Schiff bases exhibit singlet signals at 12.2-12.8, 11.2-11.3 and 2.1 ppm due to enolic $\mathrm{OH}, \mathrm{COOH}$, and methyl group attached with azomethine carbon atom, protons respectively. The resonance due to phenolic $-\mathrm{OH}$ in $\mathrm{L}_{1}$ was observed at $8.7 \mathrm{ppm}$. The signal due to proton attached with alkene carbon was observed at 5.1-5.2 ppm. In $\mathrm{L}_{3}$ a multiplet signal was found at $5.3 \mathrm{ppm}$ due to primary amine. A multiplet signal at $3.4 \mathrm{ppm}$ was observed due to proton of secondary amine in $\mathrm{L}_{4}$. The ${ }^{1} \mathrm{H}$ NMR of $\mathrm{VO}(\mathrm{IV})$ complexes was not recorded as all the complexes were paramagnetic in nature.[24] The conclusions drawn from these studies lend further support to the mode of bonding discussed in their IR spectra. The number of protons calculated from the integration curves and those obtained from the values of the expected CHN analyses agree with each other.

\section{3. ${ }^{13}$ C NMR Spectra}

${ }^{13} \mathrm{C}$ NMR spectra of amino-acid derived Schiff bases were recorded in DMSO and the data are given in the Experimental. The signal due to the azomethine carbon atom appears at $\delta 162.1$ and $168.2 \mathrm{ppm}$ in all the prepared compounds which confirms the condensation reaction between acetylacetone and amino-acid. Additional signal in the ${ }^{13} \mathrm{C}$-NMR spectra of the Schiff bases appears at 172.2-178.3 and 80.1-85.2 ppm indicating the alkene bond.

\subsection{Thermogravimetric Analysis}

The TGA curves of the complexes were recorded in the temperature range $30-1000^{\circ} \mathrm{C}$ and are given in Table 2 . The dehydration of the water molecules found outside the coordination sphere usually take place in the temperature range $25-220^{\circ} \mathrm{C}$. Coordinated waters are usually eliminated at higher temperatures $\left(100-315^{\circ} \mathrm{C}\right)$.[25] The organic part of the complex may decompose in one or more steps with the possibility of the formation of one or two Intermediates, calculated and estimated mass losses are comparable. The thermal decomposition of $\left[\mathrm{VO}(\mathrm{L}) \mathrm{H}_{2} \mathrm{O}\right]$ occurs in two steps. In the first step, TGA curve of oxovanadium complexes shows loss of a water molecule in the temperature range of 145-280 ${ }^{\circ} \mathrm{C}$ which corresponds to a weight loss of $5.20-6.33 \%$. In the second step a continuous weight loss in the temperature range $280-595^{\circ} \mathrm{C}$ is observed due to loss of Schiff base ligand. The final residue with attaining a constant weight roughly corresponds to $\mathrm{V}_{2} \mathrm{O}_{5}$.

\subsection{Conductance}

The molar conductivity measurements were carried out in DMSO at $10^{-3}$ molar concentration. The Molar conductance values for oxovanadium(IV) complexes are gives in Table 3. All the complexes $\left(\mathrm{C}_{1}-\mathrm{C}_{4}\right)$ have molar conductance in the range $10-25 \Omega^{-1} \mathrm{~cm}^{-2} \mathrm{~mol}^{-1}$ indicating non-electrolytic nature of the complexes.[26]

Table 2. Thermogravimetric analysis (TGA) results of oxovanadium complexes.

\begin{tabular}{cccc}
\hline Code & $\begin{array}{c}\text { Temperature } \\
\text { range }^{\circ} \mathbf{C}\end{array}$ & $\begin{array}{c}\text { Mass loss \% } \\
\text { Found (Calcd.) }\end{array}$ & Assignment \\
\hline $\mathrm{C}_{1}$ & $145-280$ & $5.23(5.20)$ & Loss of $\mathrm{H}_{2} \mathrm{O}$ \\
& $284-575$ & $75.05(74.98)$ & Loss $\mathrm{L}_{1}$ \\
& $145-280$ & $6.35(6.33)$ & Loss of $\mathrm{H}_{2} \mathrm{O}$ \\
$\mathrm{C}_{2}$ & $285-584$ & $70.02(69.22)$ & Loss $\mathrm{L}_{2}$ \\
& $145-280$ & $5.86(5.78)$ & Loss of $\mathrm{H}_{2} \mathrm{O}$ \\
$\mathrm{C}_{3}$ & $282-595$ & $72.15(72.02)$ & Loss $\mathrm{L}_{3}$ \\
& $145-280$ & $5.36(5.30)$ & Loss of $\mathrm{H}_{2} \mathrm{O}$ \\
$\mathrm{C}_{4}$ & $284-575$ & $74.49(74.44)$ & Loss $\mathrm{L}_{4}$ \\
\hline
\end{tabular}

\subsection{Magnetic Moments and Electronic Spectra}

The magnetic moment values of oxovanadium(IV) complexes were carried out at room temperature and are given in Table 4. The magnetic susceptibilities of VO(IV) complexes were found to be in the range of 1.74-1.86, suggesting the paramagnetic nature of the complexes. These magnetic susceptibilities of the complexes are consistent with square-pyramidal geometry around the central metal ion.[27] Electronic absorption spectral data of oxovanadium(IV) complexes along with their assignment are given in the Table IV. The electronic spectra of VO(IV) complexes exhibit three low intensities bands in the ranges $11370-13590 \mathrm{~cm}^{-1}, 15900-17150 \mathrm{~cm}^{-1}$ and $22400-23900$ $\mathrm{cm}^{-1}$ which can be assigned ${ }^{2} \mathrm{~b}_{2 \mathrm{~g}} \rightarrow{ }^{2} \mathrm{e}_{\mathrm{g}},{ }^{2} \mathrm{~b}_{2 \mathrm{~g}} \rightarrow^{2} \mathrm{~b}_{1 \mathrm{~g}}$ and ${ }^{2} \mathrm{~b}_{2 \mathrm{~g}} \rightarrow$ ${ }^{2} a_{1 g}$ transitions respectively, characteristic of a square pyramidal ligand field around VO(IV) ion. The electronic spectra also exhibit a fourth high energy band around 29200-30250 $\mathrm{cm}^{-1}$, which can be assigned as a LMCT transition which is consistent with square pyramidal geometry around the $\mathrm{V}^{4+}$. 
<smiles>[R]C1C(=O)O[N+](O)(O)C12N=C(C)C=C(C)O2</smiles>

Figure 5. Proposed structure of oxovanadium(IV) complexes

Table 3. Physical and Analytical data of oxovanadium complexes.

\begin{tabular}{cccccc}
\hline Code & Molar conductance $\left(\mathbf{O h m}^{-1} \mathbf{c m}^{-\mathbf{2}} \mathbf{m o l}^{-1}\right)$ & Mag. moments $\left(\mu_{\text {eff }}\right.$ in BM) & \multicolumn{2}{c}{ Calcd. (Found) \% Calcd. (Found) \% Calcd. (Found)\% } \\
\hline$C_{1}$ & 13.1 & $\mathrm{C}$ & $\mathrm{H}$ & $4.95(5.01)$ & $4.05(4.12)$ \\
$\mathrm{C}_{2}$ & 14.2 & 1.74 & $38.04(38.11)$ & $5.32(5.36)$ & $4.93(4.99)$ \\
$\mathrm{C}_{3}$ & 10.0 & 1.86 & $42.45(42.41)$ & $6.48(6.52)$ & $9.00(9.06)$ \\
$\mathrm{C}_{4}$ & 25.6 & 1.82 & $38.94(38.96)$ & $5.94(6.01)$ & $16.52(16.59)$ \\
\hline
\end{tabular}

Table 4. Electronic specral data along with possible assignments of oxovanadium(IV) complexes.

\begin{tabular}{|c|c|c|c|c|c|}
\hline Code & $\lambda_{\max } \mathrm{cm}^{-1}$ & Assignment & Code & $\lambda_{\max } \mathbf{c m}^{-1}$ & Assignment \\
\hline \multirow{4}{*}{$\mathrm{C}_{1}$} & $11540-13460$ & ${ }^{2} \mathrm{~b}_{2 \mathrm{~g}} \rightarrow{ }^{2} \mathrm{e}_{\mathrm{g}}$ & \multirow{4}{*}{$\mathrm{C}_{3}$} & $11520-13360$ & ${ }^{2} \mathrm{~b}_{2 \mathrm{~g}} \rightarrow{ }^{2} \mathrm{e}_{\mathrm{g}}$ \\
\hline & $16200-16900$ & ${ }^{2} b_{2 g} \rightarrow{ }^{2} b_{1 g}$ & & $15900-17150$ & ${ }^{2} b_{2 g} \rightarrow{ }^{2} b_{1 g}$ \\
\hline & $22400-23900$ & ${ }^{2} \mathrm{~b}_{2 \mathrm{~g}} \rightarrow{ }^{2} \mathrm{a}_{1 \mathrm{~g}}$ & & $22640-23780$ & ${ }^{2} b_{2 g} \rightarrow{ }^{2} a_{1 g}$ \\
\hline & $29400-29980$ & LMCT & & $29350-30100$ & LMCT \\
\hline \multirow{4}{*}{$\mathrm{C}_{2}$} & $11370-13590$ & ${ }^{2} b_{2 g} \rightarrow{ }^{2} e_{g}$ & \multirow{4}{*}{$\mathrm{C}_{4}$} & $11390-13250$ & ${ }^{2} b_{2 g} \rightarrow{ }^{2} e_{g}$ \\
\hline & $15990-17000$ & ${ }^{2} b_{2 g} \rightarrow{ }^{2} b_{1 g}$ & & $15990-16970$ & ${ }^{2} b_{2 g} \rightarrow{ }^{2} b_{1 g}$ \\
\hline & $22780-23500$ & ${ }^{2} \mathrm{~b}_{2 \mathrm{~g}} \rightarrow{ }^{2} \mathrm{a}_{1 \mathrm{~g}}$ & & $22600-23750$ & ${ }^{2} \mathrm{~b}_{2 \mathrm{~g}} \rightarrow{ }^{2} \mathrm{a}_{1 \mathrm{~g}}$ \\
\hline & $29200-30250$ & LMCT & & $29340-30240$ & LмСт \\
\hline
\end{tabular}

\subsection{Antibacterial and Antifungal Activities}

The antibacterial and antifungal activity results of the Schiff bases $\left(\mathrm{L}_{1}-\mathrm{L}_{4}\right)$ and their oxovanadium(IV) complexes $\left(\mathrm{C}_{1}-\mathrm{C}_{4}\right)$ are given in Fig. 6 and 7 . Antimicrobial results showed that all the synthesized compounds possess biological activity. The activity generally increases with increasing the concentration of the compounds. The data revealed that the activity of the ligand enhanced on complexation but less than the standard used. This enhancement in the activity is rationalized on the basis of the structures of, $\left(\mathrm{L}_{1}-\mathrm{L}_{4}\right)$ by possessing an additional azomethine $(-\mathrm{C}=\mathrm{N})$ linkage which imports in elucidating the mechanism of transamination and resamination reactions in biological system. It has also known that the ligands with nitrogen and oxygen donor systems might inhibit enzyme production, since the enzymes which require these groups for their activity appear to be especially more susceptible to deactivation by the metal ions upon chelation.[28] On chelation the polarity of the metal ion will be reduced to a greater extent due to overlap of the ligand orbital and partial sharing of positive charges of metal ion with donor groups. Further it increases the delocalisation of pi electrons over the whole chelate ring and enhances the lipophilicity of the complex. This again enhances the penetration of complexes into lipid membrane and blocking the metal bonding sites on enzymes of micro organisms, hence increases the biological activity.[29] 


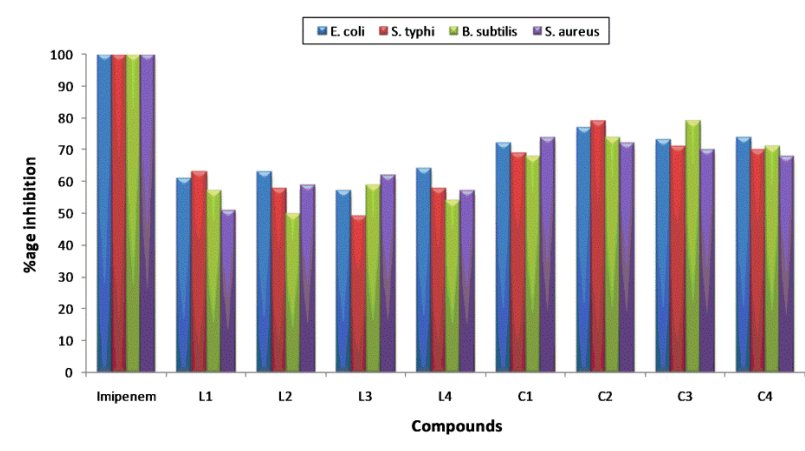

Figure 6. In vitro antibacterial spectrum of Schiff bases $\left(L_{1}-L_{4}\right)$, oxovanadium(IV) complexes and Imipenem (Std.) at $100 \mu \mathrm{gml}^{-1}$ concentration.

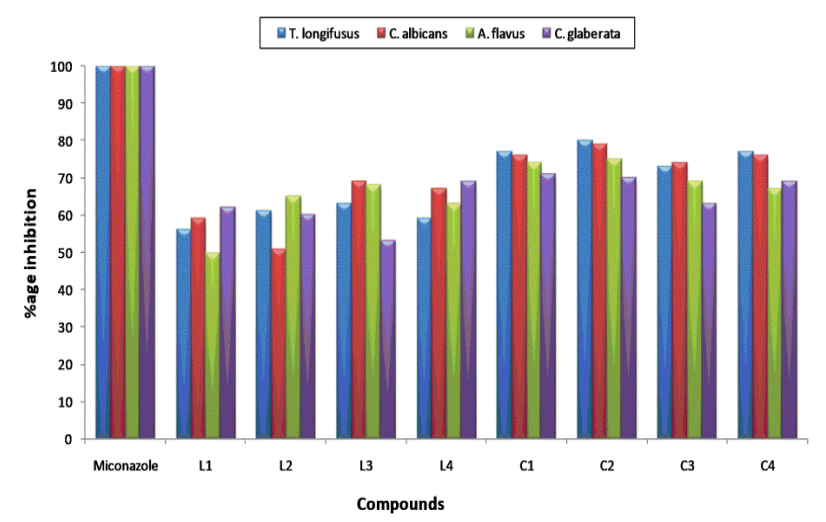

Figure 7. In vitro antifungal spectrum of Schiff bases $\left(L_{1}-L_{4}\right)$, oxovanadium(IV) complexes and Miconazole (Std.) at $100 \mu \mathrm{gml}^{-1}$ concentration.

\subsection{Cytotoxicity}

All the synthesized compounds were screened for their cytotoxicity (brine shrimp bioassay) using the protocol of Meyer et al. The cytotoxicity results are given in Table 5. In case of cytotoxic activity it was observed that all the compounds and their oxovanadium(IV) complexes gave values of $\mathrm{LD}_{50}$ therefore can be considered as non-cytotoxic.

Table 5. Brine shrimp bioassay data of the Schiff bases $\left(L_{1}-L_{4}\right)$ and their oxovanadium complexes $\left(C_{1}-C_{4}\right)$.

\begin{tabular}{cccc}
\hline Code & LD $_{\mathbf{5 0}}(\mathbf{M})$ & Code & $\mathbf{L D}_{\mathbf{5 0}}(\mathbf{M})$ \\
\hline $\mathrm{L}_{1}$ & $>3.36 \times 10^{-3}$ & $\mathrm{C}_{1}$ & $>2.61 \times 10^{-3}$ \\
$\mathrm{~L}_{2}$ & $>2.03 \times 10^{-3}$ & $\mathrm{C}_{2}$ & $>2.02 \times 10^{-3}$ \\
$\mathrm{~L}_{3}$ & $>2.94 \times 10^{-3}$ & $\mathrm{C}_{3}$ & $>1.30 \times 10^{-3}$ \\
$\mathrm{~L}_{4}$ & $>2.87 \times 10^{-3}$ & $\mathrm{C}_{4}$ & $>3.11 \times 10^{-3}$ \\
\hline
\end{tabular}

\section{Conclusion}

The synthesized Schiff bases act as tri-identate ligands. The IR, TGA, conductivity, magnetic and electronic studies confirm that the vanadyl ion is coordinated to azomethine-N, deprotonated-O of carboxylic group and enolic-O group of acetylacetone. All the derivatives and their oxovanadium(IV) complexes were evaluated in vitro against four bacterial (two Gram-negative, two Gram-positive) and four fungal strains. All the compounds and their metal complexes showed significant antibacterial and antifungal potency. Brine shrimp bioassay data reveled that all the compounds were non-cytotoxic against Artemia salina.

\section{Acknowledgements}

The author thanks to the Higher Education Commission (HEC), Government of Pakistan for awarding Indigenous Scholarship and supporting research facilities. We also thank to QAU, Islamabad for providing spectroscopic services. Finally, HEJ Research Institute of Chemistry, University of Karachi is also acknowledged for undertaking the biological assays.

\section{References}

[1] A. Elmali, M. Kabak, Y. Elerman, , "Keto-enol tautomerism, conformations and structure of N-(2-hydroxy-5methylphenyl), 2-hydroxybenzaldehydeimine," J. Mol. Struct. 2000: 477(1-3): 151-158.

[2] A. M. EI- Hendawy, E. G. EI-Kourashy, M. M. Shanab, "Schiff base complexes of ruthenium(III), molybdenum(VI) and uranium(VI), and use of the former as catalytic organic oxidants" Polyhedron. 1992: 11: 523-530.

[3] A. L. Lehlinger, "Biochemistry", $2^{\text {nd }}$ Ed. Worth Publisher, 1975: 563-564.

[4] A. D. Garnovskii, A. L. Nivorozhkin, V. I. Minkin, "Ligand environment and the structure of schiff base adducts and tetracoordinated metal-chelates" Coord. Chem. Rev. 1993: 126(1-2): 1-69.

[5] W. T. Anna, J. L. Eric, A. K. Michael, Lai, A. K. Tasneem, "Novel N-hydroxyguanidine derivatives as anticancer and antiviral agents". J. Med. Chem. 1984; 27 (2):236-238.

[6] H. W. Pou, G. K.James, J. L. Eric, M. C. Michael, "Design, synthesis, testing, and quantitative structure-activity relationship analysis of substituted salicylaldehyde Schiff bases of 1-amino-3-hydroxyguanidine tosylate as new antiviral agents against coronavirus". J. Med. Chem. 1990: 33 (2): 608-614.

[7] Z. Travnicek, M. Malon, Z. Sindelar, K. Dolezal, J. Rolcik, V. Krystof, M. Strnad, J. Marek, "Preparation, physicochemical properties and biological activity of copper(II) complexes with 6-(2-chlorobenzylamino)purine $\left(\mathrm{HL}_{1}\right)$ or 6-(3-chlorobenzylamino)purine $\left(\mathrm{HL}_{2}\right)$. The single-crystal X-ray structure of $\left[\mathrm{Cu}\left(\mathrm{H}^{+} \mathrm{L}_{2}\right)_{2} \mathrm{Cl}_{3}\right] \mathrm{Cl} \cdot 2 \mathrm{H}_{2} \mathrm{O}$ ” J. Inorg. Biochem. 2001: 84(1-2): 23-32

[8] S. Iffet, L. Elif, A. Seza, S. Nurşen, S. Nazmiye, "Antimicrobial activities N-(2-hydroxy-1-naphthalidene)-amino acid(glycine, alanine, phenylalanine, histidine, tryptophane) Schiff bases and their manganese(III) complexes." Biometals. 2004: 17 (2):115-120. 
[9] F. T. G. Huadson, "Vanadium Toxicology and Biological Significance" Elsevier, New York, 1996.

[10] Z. H. Chohan, M. Arif, M. A. Akhtar, C. T. Supuran, "Metal-Based Antibacterial and Antifungal Agents: Synthesis, Characterization, and In Vitro Biological Evaluation of $\mathrm{Co}(\mathrm{II}), \mathrm{Cu}(\mathrm{II}), \mathrm{Ni}(\mathrm{II})$, and $\mathrm{Zn}$ (II) Complexes With Amino Acid-Derived Compounds" Bioinorg. Chem. Appl. 2006; 2006: 83131: 1-3.

[11] J. Selbin, "Oxovanadium(IV) complexes". Coord. Chem. Rev. 1966: 1 (3): 293-314.

[12] M. D. John, M. Alan, R. T. Ian, "Characterization of the ground ionic state of the NS molecule using photoelectron spectroscopy". J. Chem. Soc., Faraday Trans. 2. 1977: 73:147-151.

[13] L. C. Richard, A. F. Walker, "Thermodynamics of Coordination to an Unsolvated Position in Vanadyl Acetylacetonate". J. Am. Chem. Soc. 1965: 87 (10):2128-2133

[14] Atta-ur-Rahman, M. I. Choudhary, W. J. Thomsen, "Bioassay techniques for drug development", Harwood Academic Publishers, The Netherlands, 2001, pp. 16.

[15] Atta-ur-Rahman, M. I. Choudhary, W. J. Thomsen, "Bioassay techniques for drug development" Harwood Academic Publishers: The Netherlands, 2001, pp. 22.

[16] B. N. Meyer, N. R. Ferrigni, J. E. Putnam, L. B. Jacobsen, D. E. Nichols, J. L. McLaughlin, "Brine shrimp: a convenient general bioassay for active plant constituents," Planta Medica 1982: 45 (1):31-34.

[17] A. W. Bauer, W. M. Kirby, J. C. Sherris, M. Turck, "Antibiotic susceptibility testing by a standardized single disk method" Am J. Clin. Pathol. 1966: 45 (4): 493-496.

[18] R. L. Carlin, "Transition Metal Chemistry" 2nd ed. New York, 1965.

[19] L. J. Bellamy, "The Infrared Spectra of Complex Molecules", John Wiley \& Sons: New York, 1971.
[20] J. R. Ferrero, Low-Frequency Vibrations of Inorganic and Coordination Compound, JohnWiley \& Sons: New York, 1971.

[21] K. Nakamoto, "Infrared Spectra of Inorganic and Coordination Compounds", 2nd ed. Wiley Interscience: New York, 1970.

[22] G. Singh, P. A. Singh, K. Singh, D. P. Singh, R. N. Handa, S. N. Dubey, "Synthesis and structural studies of some bivalent metal complexes with bidentate Schiff base ligands," Proceedings of National Academy of Sciences India 2002: 72 (A-2): 87-95.

[23] W. W. Simmons, "The Sadtler Handbook of Proton NMR Spectra", Sadtler Research Laboratories: Philadelphia, 1978.

[24] D. J. Pasto, "Organic Structure Determination", Prentice Hall, London, 1969.

[25] G. G. Mohamed, Z. H. Abd El-Wahab, "Salisaldehyde-2-aminobenzimidazole schiff base complexes of $\mathrm{Fe}(\mathrm{III}), \mathrm{Co}(\mathrm{II}), \mathrm{Ni}(\mathrm{II}), \mathrm{Cu}(\mathrm{II}), \mathrm{Zn}(\mathrm{II})$ and Cd(II)" J. Therm. Anal. Calorim. 2003: 73:347-359.

[26] S. R. Aswale, P. R. Mandlik, S. S. Aswale, A. S. Aswar, "Synthesis and characterization of $\mathrm{Cr}(\mathrm{III}), \mathrm{Mn}(\mathrm{III}), \mathrm{Fe}(\mathrm{III})$, Ti(III), VO(IV), Th(IV), Zr(IV) and UO2(VI) polychelates derived from bis-bidentate salicylaldimine Schiff base" Indian J. Chem. 2003: 42A:322-326.

[27] R. K. Agarwal, I. Chakraborti, "Synthesis and characterization of some oxocation (IV) coordination compounds of Schiff bases derived from 4-aminoantipyrine" Polish J. Chem. 1994: 68(8):1085-1091.

[28] Z. H. Chohan, "Antibacterial copper(II) complexes of $1,1^{\prime}$-symmetric ferrocene-derived Schiff-base ligands: studies of the effect of anions on their antibacterial properties"Appl. Organomet. Chem. 2002: 16:17-20.

[29] Z. H. Chohan, M. Arif, Z. Shafiq, M. Yaqub, C. T. Supuran, "In vitro antibacterial, antifungal \& cytotoxic activity of some isonicotinoylhydrazide Schiff's bases and their cobalt (II), copper (II), nickel (II) and zinc (II) complexes"J. Enzyme Inhib. Med. Chem. 2006: 21: 95-103. 